\title{
A Critical Assessment of Demand Response Programs Applied for Optimal Energy Management in Microgrids
}

\author{
Meenakshi De, G. Das, Kamal K. Mandal, B. Tudu
}

\begin{abstract}
Microgrid Energy Management is done to optimize microgrid performance. Power from Wind Turbines (WT) and Photo Voltaic (PV) modules into a microgrid addresses both factors of environmental concerns as well as sustainable energy production. Point of coupling with utility main grid is disconnected when microgrid functions in autonomous mode and it enhances steady microgrid operation when traditional grids face blackouts. Clean and renewable energy sources being easily affected by variation in weather condition, so taking into account of this uncertainty is essential while formulating power flow problem which can be done through demand response programs. This paper aims to investigate results obtained from research of several researchers scrutinizingly and analyzed critically for optimal energy management in microgrids using demand response programs. This paper also highlights the worthy findings of possible areas of research that would enhance the use of demand side management through demand response programs in microgrids.
\end{abstract}

Keywords: Demand Response Programs (DRP), energy management, microgrids, sustainable energy.

\section{INTRODUCTION}

The high rate of inclusion of distributed energy resources provides the advantage of clean and green energy production but at the same time possess system uncertainty. The immense increase in requirement of stable, adjustable and excellent power supply considering healthy ecosystem motivates idea of microgrid power supply. These types of power sources include Wind and PV power generation which is innately unpredictable in nature, thus causes irregular power production. Concepts such as smart grid and microgrid, nested microgrid are relatively new and are being developed in recent years.

In a microgrid system, different distributed resources are

Revised Manuscript Received on August 16, 2019.

Meenakshi De, Power Engg. Dept., J. U, Kol:7000106,

Email: meenakshide.pe.rs@ jadavpuruniversity.in,

meenakshide.ju@gmail.com

G. Das, Email: gourabdas.ju@gmail.com

Kamal K. Mandal, Email: kkm567@yahoo.co.in

B. Tudu, Email: bhimsen ju@yahoo.co.in

This work is supported by RUSA 2.0 Scheme of Jadavpur University, Kolkata, India. incorporated. Microgrids can be differentiated as AC or DC microgrids. In recent times, increase in amount of renewable energy is introduced in local and regional grids in order to reduce serious environmental pollution, improve energy efficiency and reinforce power system stability. An optimal energy management strategy can provide significant benefits such as minimization of power loss, improvement of voltage profiles, reduction of power system cost, and can serve the demand for peak load. In many practical applications, it is observed that a specified voltage and frequency is required which can guarantee robust and healthy system operation [1]. In grid connected operating mode the microgrid faces several issues that influence power supply quality. Load division among distributed-generation units should be governed by an appropriate load sharing mechanism $[2,3]$. The performance characteristics of the microgrid is highly influenced due to main utility, hence it is essential to regulate both active and reactive power thereby managing microgrids produced power [4]. The research work carried out by authors in [5] illustrated chance of development of various unreliable events like electric line disruptions, high demand in electricity and sudden price elevations affect the reliability of microgrid operation. In some literature [6] net- present-value (NPV) is utilized - a financial scale to justify microgrid expenditure. Objective function formulation included the total expenses of initial investment costs, operation costs, maintenance expenses, costs related to minimize energy which was not delivered. In recent years some studies have researched and proposed a stochastic framework [7] which helped to investigate effects of uncertainty in management and operation of microgrids.

In this paper the classification, techniques and implementation of DRP for optimal energy management of microgrids is carried out. Different types of optimization approaches, type of demand response method used and results obtained are presented in tabular form.

This research work can be divided: Sec. II discusses demand response and its classification. Section III and section IV presents price based programs and incentive based programs respectively. Section V illustrates emerging technology and case study for energy management in microgrids, Section VI is devoted to implementation of demand response programs. Finally the last section provides the paper conclusion. 


\section{DEMAND RESPONSE}

DRPs are classified depending upon their type i.e. on (a) Motivation Method/ Trigger Criteria, (b) process by which participating customers react depending on their individual load types, viz. small, medium or high loads [8].

\section{A. Different types of DRPs}

Depending upon their type, DR is divided- Incentive-Based packages (IBP) / Price-Based (PB). IBP are those where consumers are provided remittance for delivering certain quantity of load curtailment in specific time domain. PB demand response comprises of participation of customers in response to economic variations of the market. Fig. 1 shows various types in DRPs.

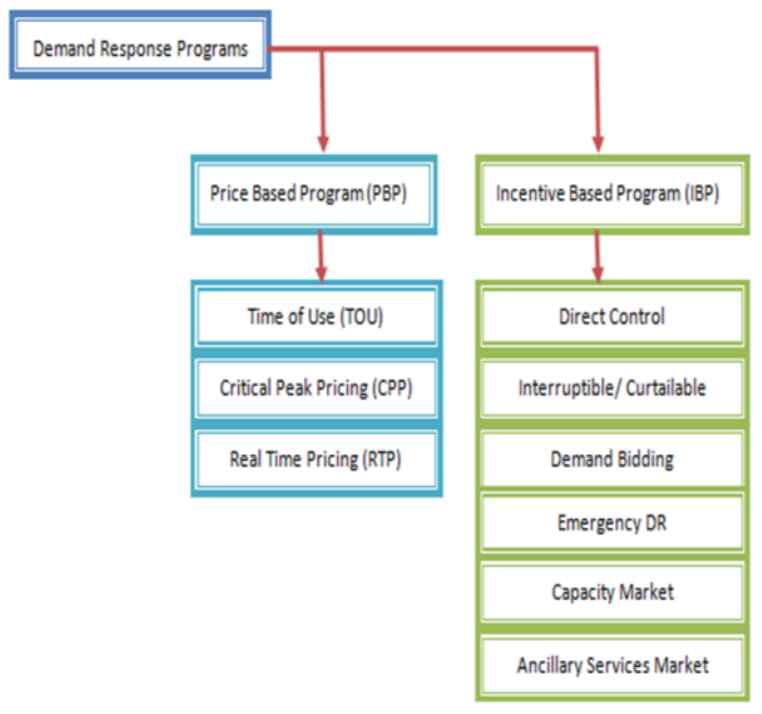

Fig. 1.Types of DRPs

\section{PRICE BASED PROGRAMS}

The different types in PBP discussed as follows:

\section{A. TOU}

Generally offered on customers by power utility or the service provider in order to enhance electricity system operation and are promoted by the power utility regulators for enhancing economic efficiency. Time variant pricing is a process in order to share the price risks between utility service provider and consumer. The high income group households tend to perform better to demand response pricing for higher economic gains as these customers utilize high end advanced devices. The middle income groups and low income groups who cannot afford such high end gadgets and devices are exposed to negative impacts of demand response pricing. These types of tariff programs have been illustrated in [9].

\section{B. Critical Peak Pricing}

Critical Peak Pricing is defined as electric commodity rate which is applicable to such consumers where electricity demand equals to or exceeds critical peak demand. Critical peak pricing is applicable in cases when extreme hot weather conditions prompt peak usage of air conditioning machines or other heavy loads. Critical peak pricing tariff takes into account the cost of taking appropriate action by pre-committing to a critical pricing event usually lasting for about 4 to 6 hours [10]. During critical peak pricing hours, retail prices are usually set to high values. During times of peak energy demand, such as hot summer days, the electric power system requires more power than is typically available. The critical peak pricing program will provide consumers a price signal to encourage them to reduce their electricity during these periods. Participating consumers can save between five to ten percent on their annual energy electric bill which depends on load reduction.

\section{Real Time Pricing}

Real-Time-Pricing refers to demand side package where energy charge is changed within small time, i.e., at hour basis, illustrated in [11]. Also, real-time-pricing technique may achieve revenue at elevated rate, at the same time curtail electricity bill of customers.

\section{INCENTIVE BASED PROGRAMS}

Different kinds in IBP:

\section{A. Direct control}

The main aim of direct load control is engagement of sufficiently large number of small customers such as in residential loads [12]. By these Programs, power system will regulate particular load types at receiving side. Such loads are generally those with tendency of high power consumption.

\section{B. Interruptible/ Curtailable}

This type of load reduction programs are designed based on requirements of medium and large customers. Participation in these types of programs is compulsory such that the participant customers may face high penalty in situations of failure to respond to DR occurrences [13].

\section{Demand bidding}

Demand side bidding provides a very interesting offer to the end consumers. This type of demand response programs provide customers with chance to engage in electrical power market by means of giving load curtailment proposals. There are several methods by which end customers can participate in demand side bidding. Large consumers can participate in the bid market and install state of art load management tools. Relative small consumers take part in demand response programs through third party bidders. Load serving entities (LSEs) take part in power market as planned bidder and offer coupon based DR programs to end users [14].

\section{Emergency demand response}

The Emergency Demand Response (EDR) represents preventive demand response which is implemented in times of power shortfall [15]. It is a widely adopted preventive type demand response program. Emergency demand response programs protect the power grid by way of coordinating multiple power consumers to shed loads during emergency circumstances. 
In most cases emergency DR is likely to occur in natural disasters or in extreme weathers. Increased inclusion of renewables into the grid, production shortfalls are likely to increase, discrepancy between generation and consumption arises thus emergency DR may exhibit vital part for stabilizing utility, providing balance between supply and demand.

The following section describes the capacity and ancillary services of power system operation.

\section{E. Capacity and Ancillary Services}

Capacity and Ancillary Services: The necessity of capacity market arises from market failures, particularly from low demand flexibility of energy markets. According to Central Electricity Regulatory Commission, Part of Regulation (2) (1) (b) of Indian-Electricity-Grid-Code, 2010 [16], Ancillary Services are defined as services needed in helping Electrical Network performance to get satisfactory Power-Quality, Reliability \& Stability. Fig. 2 shows ancillary services.

\section{ENERGY MANAGEMENT IN MICROGRIDS}

The method of meeting customer's requirements and reducing greenhouse effusion is through utilization of distributed generations. Recently, microgrids as small scale power producing units incorporating renewable sources of energy are introduced as emerging technology and its management becomes necessary as illustrated in [17-19]. The aforementioned papers used various strategies for expert management system in microgrids.

\section{A. Case-Study in microgrids}

Microgrid case study is illustrated in [20]. The microgrid comprising of several generation and storage units, Micro-Turbine (MT), Fuel-Cell (FC), battery, renewable sources utilizing photovoltaic (PV), wind turbines (WT) is considered for the research work in aforementioned paper where demand response programs are implemented. Table I presents the recent literature review on energy management in microgrids where various innovative technologies are adopted.

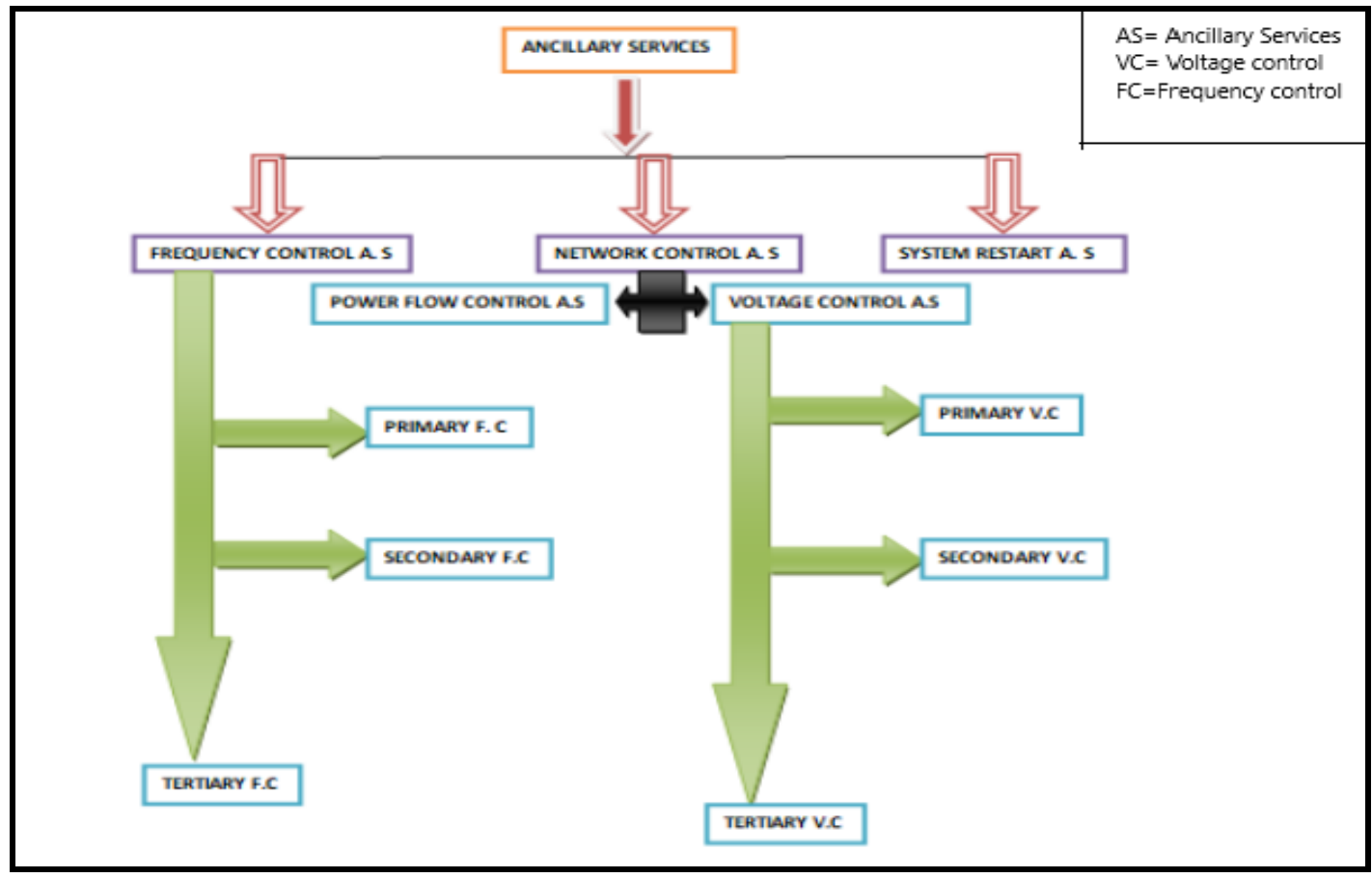

Fig. 2. Ancillary services 
Table- I: Energy management in microgrids

\begin{tabular}{|c|l|l|l|l|}
\hline Reference & Year & \multicolumn{1}{|c|}{ Findings } & \multicolumn{1}{|c|}{ Advantages } & \multicolumn{1}{|c|}{ Limitations } \\
\hline$[21]$ & 2019 & $\begin{array}{l}\text { Correlated operation in } \\
\text { microgrids using hybrid } \\
\text { Sources. }\end{array}$ & $\begin{array}{l}\text { Smooth grid synchronization } \\
\text { and connection; safe } \\
\text { performance in various } \\
\text { electricity production \& } \\
\text { Consumption- situations. }\end{array}$ & $\begin{array}{l}\text { Interesting to note the observations } \\
\text { when multiple microgrids are } \\
\text { associated not considered in the } \\
\text { work. }\end{array}$ \\
\hline$[22]$ & 2018 & $\begin{array}{l}\text { Online Energy Management } \\
\text { System (EMS) using Distributed } \\
\text { Algorithm in microgrids. }\end{array}$ & $\begin{array}{l}\text { The Online Algorithm gives } \\
\text { efficient scheduling compared } \\
\text { to Robust-Optimization method. }\end{array}$ & $\begin{array}{l}\text { The units, Regret \& Competitive } \\
\text {-Ratio, seems contradictory. } \\
\text { Algorithm for reducing regret } \\
\text { cannot decrease competitive ratio. }\end{array}$ \\
\hline$[23]$ & 2018 & $\begin{array}{l}\text { Presents Nested EMS for } \\
\text { day-ahead schedule in } \\
\text { microgrids. }\end{array}$ & $\begin{array}{l}\text { Operating cost lower in in } \\
\text { networked microgrids. }\end{array}$ & $\begin{array}{l}\text { Consumers privacy (of nested } \\
\text { EMS) is layered where privacy of } \\
\text { outermost layer is weakest. }\end{array}$ \\
\hline
\end{tabular}

VI. I

\section{MPLEMENTATION OF DRPS}

DRPs are illustrated in different literatures [24-26] that is implemented in power networks. The aforementioned papers also focus on techniques to cover unpredictability due to Wind Turbine and Solar Cells.

\section{A. Types of DR Participants}

A scheduling model and illustration of various types of DR participants can be found in [20, 27]. In these papers, three load curtailment intervals and three Energy charges of Residential, Commercial and Industrial customers are considered. Types of DR participants i.e., Residential, Commercial and Industrial loads are shown in Fig. 3.

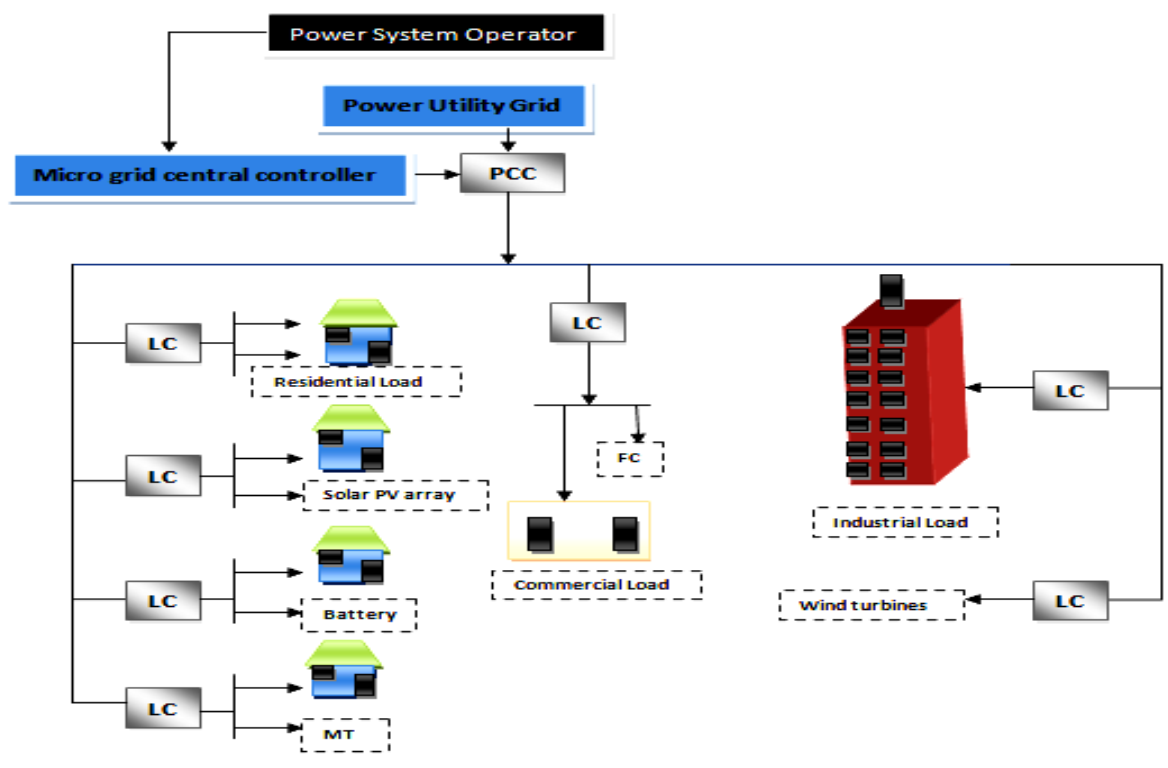

Fig. 3. Types of DR participants 
Table II presents the results Of DRPs for Energy management in microgrids.

Table- II: Results obtained from DRPs for Energy management in microgrids

\begin{tabular}{|c|c|c|c|c|}
\hline Reference & Aim/ Objective & $\begin{array}{c}\text { Optimization } \\
\text { approach }\end{array}$ & Demand response Method used & Results obtained \\
\hline [28] & $\begin{array}{l}\text { Obtain minimum } \\
\text { electricity cost }\end{array}$ & $\begin{array}{ll}\text { Integer } & \text { linear } \\
\text { programming } & \end{array}$ & $\begin{array}{l}\text { The proposed method decides when } \\
\text { consumer devices are ON/OFF. }\end{array}$ & $\begin{array}{l}\text { This type- control technique gives } \\
\text { optimal points within definite } \\
\text { schedule period. }\end{array}$ \\
\hline [29] & Minimum consumption & $\begin{array}{l}\text { Mixed integer } \\
\text { programming }\end{array}$ & $\begin{array}{l}\text { Load distribution variations changes } \\
\text { electricity prices. }\end{array}$ & $\begin{array}{l}\text { Efficient load scheduling \& } \\
\text { estimate of Storage-Capacity is } \\
\text { achieved. }\end{array}$ \\
\hline$[30]$ & $\begin{array}{l}\text { Minimum cost and } \\
\text { minimum consumption }\end{array}$ & $\begin{array}{l}\text { Mixed Integer Linear } \\
\text { Programming }\end{array}$ & $\begin{array}{l}\text { Recommended a Residential } \\
\text { energy-management-system. }\end{array}$ & $\begin{array}{l}\text { Resolved Optimization Problem of } \\
\text { Cost \& Power. }\end{array}$ \\
\hline [31] & Profit Maximization & $\begin{array}{l}\text { Mixed Integer (MI) } \\
\text { Non-linear } \\
\text { Programming (NLP) }\end{array}$ & Pricing for short intervals. & Low costs to the consumers. \\
\hline$[32]$ & Reducing energy costs & $\begin{array}{l}\text { Mixed discrete/ } \\
\text { continuous } \\
\text { Non-linear } \\
\text { Programming }\end{array}$ & $\begin{array}{l}\text { Price responsive Demand Side Management } \\
\text { (DSM). }\end{array}$ & $\begin{array}{l}\text { Satisfy higher loads \& reduce Costs } \\
\text { through } \\
\text { Renewable-energy-systems } \quad \& \\
\text { Price-responsive-demands. }\end{array}$ \\
\hline$[33]$ & Reduce costs & NLP & Seasonal flat pricing & $\begin{array}{l}\text { Efficient power-price model } \\
\text { considering Smart-meters \& DSM. }\end{array}$ \\
\hline [34] & Reduce customer bill & Heuristics & load shifting technique & $\begin{array}{l}\text { Expeditious method leads to } \\
\text { optimal points. }\end{array}$ \\
\hline$[35]$ & $\begin{array}{l}\text { Minimize operational } \\
\text { cost and } \mathrm{CO}_{2} \text { emissions } \\
\text { reduction }\end{array}$ & $\begin{array}{l}\text { Particle Swarm } \\
\text { Optimization }\end{array}$ & $\begin{array}{l}\text { Scheduling \& intelligent control in } \\
\text { Energy-System components. }\end{array}$ & Intensive usage of Renewables. \\
\hline [36] & Minimum cost & $\begin{array}{l}\text { Binary Particle } \\
\text { Swarm Optimization }\end{array}$ & $\begin{array}{l}\text { Dynamic distributed-resource-management } \\
\& \text { efficient performance of Residential } \\
\text { devices in DSM-based-simulation } \\
\text { technique. }\end{array}$ & Efficient resource management. \\
\hline [37] & Minimum cost & $\begin{array}{l}\text { Stochastic } \\
\text { optimization }\end{array}$ & Considers fixed \& shiftable load Demands. & $\begin{array}{l}\text { Efficiently solved the optimization } \\
\text { problem by taking into account } \\
\text { different Domestic equipments, } \\
\text { Renewables \& Power storing } \\
\text { apparatus. }\end{array}$ \\
\hline [38] & Maximum welfare & $\begin{array}{l}\text { Markov Decision } \\
\text { approach }\end{array}$ & Centralized controller based DSM. & $\begin{array}{l}\text { Centralized Management to control } \\
\text { Charging-Stations used in plug-in } \\
\text { Hybrid electric-vehicles. }\end{array}$ \\
\hline [39] & $\begin{array}{l}\text { Minimum cost, } \\
\text { minimum consumption }\end{array}$ & $\begin{array}{l}\text { Robust optimization } \\
\text { method }\end{array}$ & $\begin{array}{l}\text { Determination of appropriate consumption } \\
\text { scheduling. }\end{array}$ & $\begin{array}{ll}\text { Robust-Optimization } & \text { framework } \\
\text { thoroughly solves } & \text { issue of } \\
\text { Correlated-Price-Data. } & \end{array}$ \\
\hline
\end{tabular}

\section{CONCLUSION}

This research paper presented thorough background as well as key features in optimal energy management of microgrid. We also provided critical review on the implementation of DR programs and types of DR participants, represented detailed results of demand response programs applied for energy management in microgrids including objective, optimization model, demand response method used and illustration of results.

Attractive charges are incorporated in package-prices to motivate consumers in DRPs. These appealing packages model the boundary conditions for customers included in demand-response management. As renewable energy sources like power produced from Wind Turbines and Photovoltaic modules possess intermittent nature, so procedures of energy management in microgrids would be stochastic.

Enhanced customer involvement obtained by various DRP contracts, show various energy consumption choices.

Furthermore, inclusion of sophisticated technology and advanced communication infrastructure between service providers and end users can be implemented in future work which can inspire worthy research in demand side management techniques in microgrids.

\section{ACKNOWLEDGEMENT}

Authors would like to acknowledge and thank Department-Power Engineering, J. U. and RUSA 2.0, J.U for its assistance and necessary help.

\section{REFERENCES}

1. Y. Wei et al. "A Scheme connecting microgrid AC Grid Via Flexible Power Elec. Interface," International Conference on Power-Sys. Tech., 2010, pp.1-6.

2. R. Majumder, "Improvement Stability \& Load Sharing Autonomous Microgrid Using suppl. Droop Control Loop," IEEE-Transactions Powe- Sys, vol. 25, 2010, pp.796-808.

3. S. J. Ahn et al., "Power sharing Method In Multiple Distributed Generators Considering Control Modes And Configurations Of A Microgrid," IEEE-Trans P. Del., vol. 25, 2010, pp. 2007-2016.

4. I.Vechiu et al., "Control Power Converters Microgrids," Intl. J. Comp. \& Mathematics Elec. \& Electronic Engg., vol. 30, 2011, pp. 300-309.

5. E. Kuznetsova et al., "Analysis Robust Opt. Decentr. Microgrid Energy Mgmt Under Uncertainty,” Intl. J Elec. P. and E. Sys., vol. 64, 2015, pp. 815- 832 .

6. M. H. Moradi, "Hybrid Method Simultaneous Optim. DG Cap. \& oper. Strat. M.grids cons. Uncertainty Electricity Price Forecasting,” Intl. J Renew. E., Vol.68, 2014, pp. 697-714.

7. S. Mohammadi, "Sc. based Stoc. Oper. Mngmnt Microgrid incl. Wind, P.V., MicroTur., F. Cell \& E. storage," Int. J Elec. P. and E. Sys.,Vol. 54, 2014, pp. 525- 535 . 
8. J. Vardakas et al., "A Sur. Dem. Res. Prog. S. Grids: Pr. Methods \& Optim. Algo.," IEEE-Comm. Surveys-and Tut., vol. 17, 2015, pp.152-178.

9. J. N. Rai et al., “T. Sett. I. P. Sec.-an overview,” IOSR J. Elect. and electronics Engg., Vol. 6, Issue-1, 2013, pp. 97-108.

10. M. Kii et al., "The eff. Critical Peak Pricing elec. Dem. mgmt on home-based trip generation," Intl. Asso. Traffic \& Safety- Sc., IATSS Res., Elsevier Ltd., vol. 37, 2014, pp. 89- 97.

11. B. Xu et al., "A Comp. Pol. participation storage U.S. freq. Reg. markets," IEEE -PES Gen. meeting, 2016.

12. A. Salami, "Dem. Side Mgmt Using Direct L.C For Residential \& Industrial Areas," Intl. Cong. Electric Industry Automation, 2015.

13. H. Aalami et al., "Dem. Resp. Modeling Considering interruptible/curtailable Loads \& Capacity Market Programs," Applied -Energy, vol. 87, Issue -1, 2010, pp. 243- 250.

14. J. Saebi et al., "demand Bidding/buyback modeling \& its impact Mkt clearing price," IEEE- Intl. energy conf., 2010, pp.791-796.

15. D. Kim et al., "Des. Of emergency demand response program using analytic hierarchy process," IEEE-Trans. smart grid, vol. 3, Issue-2, 2012, pp. 635 - 644.

16. Central Electricity Regulatory Commission, New Delhi, IEGC Regulations, 2010. The Gazette of India, part 3, section 4, 2010, pp. 86-193.

17. U.S.-Dept. Of energy: "BENEFITS Of Demand Response in Electricity Markets \& Recommendations For Achieving Them," 2006.

18. M, Motevasel, "Exp. Energy Mgmt Of microgrid Considering WindEnergy- Uncertainty," Eg.y Conv. Mgmt.,2014, pp. 58- 72.

19. C. Chen et al., "SMART ENERGY mgmt sys FOR OPTIMAL MG econ. Op.," IET-Renew-Power- Gener. vol. 5, no.3., 2011, pp. 258267.

20. G. R. Aghajan et al., "Pres. Multi-Objective gen. Sch. Model Pricing dem. Resp. Rate M.grid Energy Mgmt," E. Conv. Mgmt, 2015, pp. $308-321$.

21. J. Hu et al.,"Co-ordinated Control Of Hybrid Ac/Dc Microgrids With PV, Wind, Battery Under Variable Generation And Load Conditions," Electr. POWER and ENERGY SYSTEMS, Vol.- 104, 2019, pp. 583592.

22. W. Ma et al., "Distr. egy mgmt Networked M.Grids Using Online ADMM With Regret," IEEE-TRANS-SMART-GRID, (2018), 847-856.

23. A. Hussain et al., "Res. \& priv. Preserv. Energy Mgmt Str. For-Net. M.Grids," IEEE-trans-smart-grid,vol. 9, 2018, pp 2127- 2139.

24. A. Zakariazadeh, "Stochastic-Multi-Objective op. Planning Of Smart distr. Sys. Cons. DRPs," Electr P. Sys. R., 2014, pp.156-158.

25. P. Faria et al., "Mod. PSO appl. Integr. DR \& DG resource Sch.," IEEE-TRANS. SMART GRID, 2013.

26. H. Falsafi, "Role- DR Single \& Multi obj. Wind Thermal Gen. Sch.: Stochastic-Programming," ENERGY, vol. 64, 2014, PP. 853- 867

27. A. Moghaddam, "Multi.Obj. op. mgmt renew. M.G. With Back-Up Micro-Turbine, Fuel Cell, Battery Hyb. P. Source,” Energy, 2011, PP. $6490-6507$.

28. A. Molderink et al., "Domestic Ener. mgmt meth. Optim. eff. Smart Grids," IEEE-Power-Tech, 2009.

29. S. Choi et al., " A MG engy mgmt inducing-Opt. DR," IEEE S.G. Comm, 2011, pp. 19-24.

30. J. Wang et al., "Opt. Dispatching Model Of Smart Home Energy Mgmt Sys.," IEEE, 2012.

31. E. Sortomme et al., "Optim. Charging Str. Unidir. Veh.-to-Grid," IEEE TRANS. SMART GRID, 2011, PP. 131- 138.

32. C. Cecati et al., "Comb. Op. of renew. egy sys. \& resp. Dem. Smart grid," IEEE, Energy, Vol-2, 2011, PP 468-476.

33. M. Doostizadeh et al., "A Day-Ahead Electricity Pricing Model Based On Smart Metering And Demand-Side Management," Energy, Vol-46, 2012, PP 221-230.

34. T. Logenthiran et al., "DSM Smart Grid using heur. Optim.," IEEE Trans., Vol-3 2012, PP 1244-1252 .

35. A. Saber et al., "Eff. Util. of renew. Ener. Sources Grid-able veh. Cyb.-phy. Sys.," IEEE Syst. J., Vol-4, 2010, PP 285-294.

36. N. Gudi et al., "A Dem. Side Mgmt Based Sim. platform incorp. Heu. Optim. for mgmt Household Appl.," Int. J. Electr. P.E.S, Vol-43, 2012, pp. $185-193$.

37. Y. Guo et al.,"Optim. P. Mgmt Of Residential Customers In The Smart Grid," IEEE Tr. Pll. Distr. Sys., Vol. 23, 2012, PP. 1593-1606.

38. W. Shi, et al., "Real-Time veh.-to-Grid contr. Algor. Under Price Uncer.," IEEE S.Gr. Comm., Belgium, 2011, pp. 261 - 266.

39. R. S. Ferreira et al., "Dem. Res. Model With Corr. Price-Data: A Rob. Optim. App.," Appl. Egy, Vol-96, 2012, PP. 133 - 149.

\section{AUTHORS PROFILE}

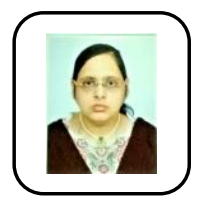

Meenakshi De received her B. tech \& M. tech in EE, West Bengal Univ. Technology. She was awarded Junior Research Fellowship from DST- GOI- PURSE in 2016. She worked as Guest Faculty and as Visiting Faculty in the Dept. Power- Engg., J U, West Bengal, India and in the Department of Information Technology, Jadavpur Univ. West Bengal. She is currently pursuing research under RUSA 2.0 scheme, J.U., West Bengal and working towards her Ph.D. degree. She has several research publications at reputed, well known International \& National Journals \& Conferences. Her present research interests are electrical power network, microgrids, soft computing techniques and optimization algorithms.

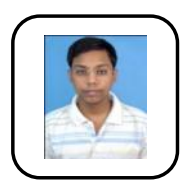

Gourab Das received B-Tech (EE) West Bengal Univ. Tech., West Bengal, India in 2009, ME degree in Nuclear Engg., Jadavpur Univ., Kolkata, India, 2012.In 2009 joined JCF, Kolkata, as a Electrical Engineer and in 2012 he joined TCS R\&D as a Assistant System Engineer and in 2013 become a System Engineer. He works as Senior Research Fellow in Power Engineering Department, Jadavpur University and also in academic areas and administrative affairs (General Manager of JCF), organized seminar, workshops. He has publications in International Journal, conferences, received a Indian Society of Lighting Engineers Scholarship and also West Bengal Government Fellowship. Present research interests are Hybrid Energy, Fuzzy Logic, Solar energy, high voltage d.c and power qualities.

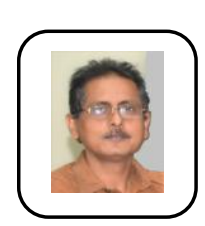

Dr. Kamal Krishna Mandal received B E in electrical engineering, Jadavpur University, West Bengal. After that he received his M.E.degree, Allahabad University, U.P \& Ph.D. in engineering, J.U, Kolkata, India. His publications spans over various reputed and well known international Journals \& Conferences. He also worked in Indian-Telephone-Industries, N. I. T, Durgapur, West Bengal \& presently engaged as Professor, Department of Power Engineering, J.U. He supervised and guided various post graduate and doctoral students in his entire teaching career. He also organized various seminars and workshops in the department. His teaching \& research interests include electrical network optimization, implementing soft-computing-techniques, commercial electrical systems.

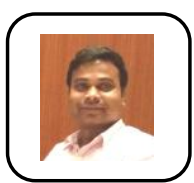

Dr. Bhimsen Tudu, Assistant Professor, Power Engineering Dept. of Jadavpur University, West Bengal He graduated in Electrical Engineering from Jadavpur University in 2005. After graduation, he became Assistant Manager in reputed private company for 3 years. He did his masters from Power Engg. Dept., J. U. and obtained his $\mathrm{Ph} . \mathrm{D}$. degree in Engineering, J.U. in 2018. His work spans several areas of electric power system and renewable energy with focus towards issues and challenges of grid integration of renewables, socio-economic and techno-economic evaluation of microgrid system, optimization of renewable energy system etc. His research publications include 38 national \& international Journal and Conference-papers.
Published By: Blue Eyes Intelligence Engineering $1 / 4$ / \& Sciences Publication 